\title{
The effect of methionine supplementation on the levels of pancreatopeptidase $E$, trypsin, chymotrypsin and amylase in the pancreas of chicks receiving raw and heated soya-bean diets*
}

\author{
BY ZAFRIRA NITSAN \\ Division of Poultry Husbandry \\ The Volcani Institute of Agricultural Research, Rehovot, Israel \\ AND A. GERTLER \\ Department of Agricultural Biochemistry and Animal Nutrition, \\ Faculty of Agriculture, Hebrew University of Yerusalem, Rehovot, Israel
}

(Received 30 March 197x - Accepted 17 August 1971)

\begin{abstract}
I. The effect of methionine supplementation upon pancreatic trypsin, chymotrypsin, pancreatopeptidase $\mathrm{E}$ and amylase of chicks given raw and heated soya-bean diets (RSD and HSD) was studied before and after fasting.

2. Statistical analysis of the ratios of amylase to pancreatopeptidase E, trypsin and chymotrypsin in each individual chick revealed that methionine supplementation consistently increased the ratio of amylolytic to proteolytic enzymes. This phenomenon was most marked in the fasted RSD group, less in the fed RSD and fasted HSD groups and least in the fed HSD group.

3. The results are discussed in relation to methionine metabolism in chicks given RSD and HSD supplemented with trypsin inhibitors.
\end{abstract}

The decreased growth rate resulting from consumption of raw soya-bean is related, at least in part, to the low availability of the sulphur-containing amino acids (Almquist, Mecchi, Kratzer \& Grau, I942) and to decreased tissue utilization of methionine (Barnes, Fiala \& Kwong, I962).

As reported earlier (Gertler \& Nitsan, I970), the addition of trypsin inhibitors to a heated soya-bean diet (HSD) increased the production of both proteolytic and amylolytic enzymes, whereas in chicks given a raw soya-bean diet (RSD) an increase in the proteolytic enzymes only was obvious. This could be a result of a greater deficiency in methionine in chicks given RSD than in those given HSD and an increased demand for this amino acid since all those enzymes mentioned above are known to be rich in cystine (Neurath, 1961), which is probably produced from methionine. Trypsin inhibitor was found to increase the conversion of methionine into cystine (Kwong \& Barnes, 1963; Barnes \& Kwong, 1965).

Lepkovsky, Koike, Sugiura, Dimick \& Furuta ( 1966 ) showed an increased production of amylase when both HSD and RSD were supplemented by methionine. The aim of the present work was to study the effect of methionine supplementation upon the levels and relative ratios among the proteolytic and amylolytic enzymes present in the pancreas of chicks given RSD and HSD.

* Contribution from the National and University Institute of Agriculture, Rehovot, Israel. 197I Series, No. 1885 -E. 


\section{EXPERIMENTAL}

\section{Diets}

The protein source of the semi-synthetic diets was either heated or raw soya-bean meal, calculated to provide $22 \%$ protein in the diet. The detailed composition of the diets is given in an earlier report (Gertler $\&$ Nitsan, 1970). DL-Methionine was added to both diets at the levels of $0,0.3$ and $0.6 \%$.

\section{Determination of enzymic actioities}

The activation of zymogens and determination of trypsin $(E C 3.4 .4 \cdot 4)$, chymo-

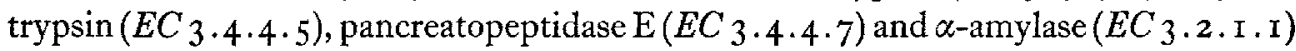
activities in the pancreas has been described previously (Gertler \& Nitsan, I970). One unit of activity of trypsin and chymotrypsin was defined as I $\mu \mathrm{mol}$ substrate (benzoylL-arginine ethyl ester hydrochloride (BAEE) and $N$-acetyl-L-tyrosine ethyl ester (ATEE) for trypsin and chymotrypsin respectively) hydrolysed $/ \mathrm{min}$ at $25^{\circ}$. One unit of pancreatopeptidase $\mathrm{E}$ was defined as the reciprocal of the time required to attain $50 \%$ digestion of Congo-red elastin measured in min and multiplied by 100 . The amylase unit was defined as an increase in $\mathrm{I} \times 10^{2}$ of extinction at $55^{\circ} \mathrm{nm}$ within $3 \mathrm{~min}$, using $1 \cdot 27 \mathrm{~cm}$ Spectronic 20 Bausch \& Lomb test-tubes.

\section{Experimental procedure}

Expt r. New Hampshire $\times$ White Leghorn male chicks, I d old, were divided into four groups of twenty and given HSD, HSD + $0.6 \%$ methionine, RSD, and RSD + $0.6 \%$ methionine respectively, from the ist day. At the age of $20 \mathrm{~d}$, ten chicks from each group were killed (fed chicks), and ten were left in the cages with water but no food for $24 \mathrm{~h}$ and were then killed (fasted chicks).

After the chicks had been killed, the pancreases were removed, cleaned of extraneous material, weighed and frozen at $-20^{\circ}$. The pancreases were kept frozen until assayed for proteolytic and amylolytic enzymes.

Expts 2 and 3 . Six groups of twenty I-d-old chicks were given HSD, HSD + $0.3 \%$ methionine, HSD $+0.6 \%$ methionine, RSD, RSD $+0.3 \%$ methionine and RSD + $0.6 \%$ methionine respectively, from the Ist day. Fed and fasted chicks were killed at the ages of $9($ Expt 2) and $20($ Expt 3$) \mathrm{d}$, and their pancreases were treated and tested for the same enzymic activities as in Expt $\mathrm{I}$. The results were analysed statistically by factorial analysis of variance and the multiple range test (Snedecor, ig62).

\section{RESULTS AND DISCUSSION}

As shown in Table $\mathrm{r}$, the addition of methionine $(0.3$ and $0.6 \%)$ to the experimental diets increased the body-weight gains only of the chicks given RSD. As expected, RSD caused significant enlargement of the pancreas, which was unaffected by the level of methionine in the diets.

The effect of methionine level in the diets upon the enzymic activities is shown in Fig. I. The fasted chicks that had received RSD always had the highest enzymic 
Table I. Effect of methionine supplementation on the body-zeight and pancreas enlargement of chicks given a raw soya-bean diet (RSD) or a heated soya-bean diet (HSD)

\begin{tabular}{|c|c|c|c|c|c|c|c|c|}
\hline \multirow[b]{2}{*}{$\begin{array}{c}\text { Expt } \\
\text { no. }\end{array}$} & \multirow[b]{2}{*}{$\begin{array}{l}\text { Age } \\
\text { (d) }\end{array}$} & \multirow{2}{*}{$\begin{array}{c}\text { Methionine } \\
\text { level } \\
\text { (\% of diet) }\end{array}$} & \multicolumn{2}{|c|}{$\begin{array}{l}\text { Final body-wt } \\
\text { (g/chick) }\end{array}$} & \multicolumn{2}{|c|}{$\begin{array}{l}\text { Body-wt gain } \\
\text { (g/d chick) }\end{array}$} & \multicolumn{2}{|c|}{$\begin{array}{c}\text { Pancreas } \\
\text { (g/100 g body-wt) }\end{array}$} \\
\hline & & & RSD & HSD & $\mathrm{RSD}$ & HSD & RSD & $\mathrm{HSD}$ \\
\hline $\mathbf{I}$ & 20 & $\begin{array}{l}\circ \\
0.6\end{array}$ & $\begin{array}{l}\text { I } 18 \\
135\end{array}$ & $\begin{array}{l}219 \\
207\end{array}$ & $\begin{array}{l}4 \cdot 2 \\
4 \cdot 9\end{array}$ & $\begin{array}{l}9 \cdot x \\
8 \cdot 5\end{array}$ & $\begin{array}{l}x \cdot 08 \\
0.95\end{array}$ & $\begin{array}{l}0.44 \\
0.47\end{array}$ \\
\hline 2 & 9 & $\begin{array}{l}0 \\
0.3 \\
0.6\end{array}$ & $\begin{array}{l}95 \\
\text { II } 3^{*} \\
\text { II }\end{array}$ & $\begin{array}{l}142 \\
148 \\
141\end{array}$ & $\begin{array}{l}4 \cdot 7 \\
6 \cdot 8 * \\
6 \cdot 6 *\end{array}$ & $\begin{array}{r}9.9 \\
10.5 \\
10.0\end{array}$ & $\begin{array}{l}0.75 \\
0.70 \\
0.79\end{array}$ & $\begin{array}{l}0.41 \\
0.41 \\
0.42\end{array}$ \\
\hline 3 & 20 & $\begin{array}{l}0 \\
0.3 \\
0.6\end{array}$ & $\begin{array}{l}176 \\
220^{*} \\
244^{*}\end{array}$ & $\begin{array}{l}275 \\
276 \\
265\end{array}$ & $\begin{array}{l}5 \cdot 8 \\
8 \cdot 1 * \\
9 \cdot 0^{*}\end{array}$ & $\begin{array}{l}10.6 \\
10.7 \\
10.2\end{array}$ & $\begin{array}{l}0.84 \\
0.75 \\
0.83\end{array}$ & $\begin{array}{l}0.36 \\
0.34 \\
0.40\end{array}$ \\
\hline
\end{tabular}

The statistical analysis was performed within each experiment. The means of the body and pancreas weights at the different methionine levels within the same diet were compared.

* Significantly different from the corresponding unsupplemented mean $(P<0.05)$.

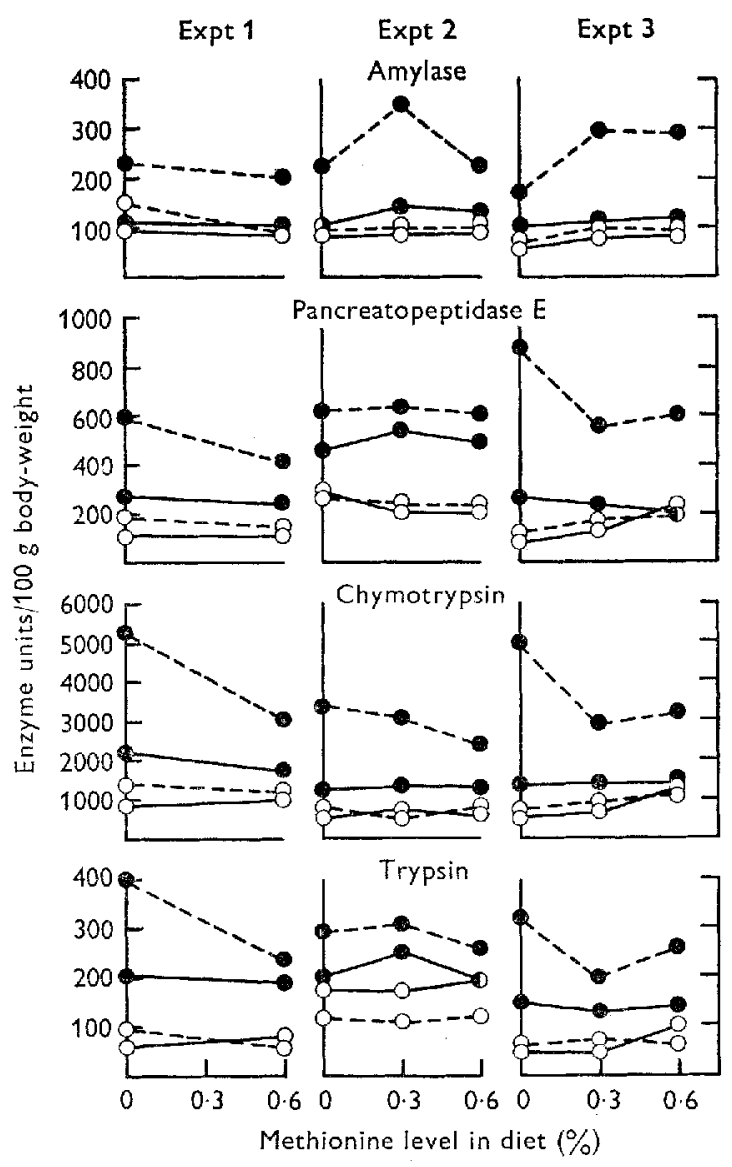

Fig. I. Effect of methionine supplementation on the level of pancreatic amylase, pancreatopeptidase $\mathrm{E}$, chymotrypsin and trypsin in chicks given raw soya-bean dict (•) or heated soya-bean diet $(0)$, before $(-)$ and after $(---)$ fasting. 
activities, which confirms previously reported results (Gertler \& Nitsan, 1970). The enzymic activities in the fed chicks were scarcely affected by the level of methionine. In the fasted chicks from the RSD group, the level of the proteolytic enzymes in methionine-supplemented groups was reduced in most instances, the decrease being more significant in the $20-\mathrm{d}$-old chicks than in the 9 -d-old ones. In the HSD group, no marked changes in the level of the proteolytic enzymes were noted as a result of methionine supplementation.

The main changes in the amylase activity occurred also in the fasted chicks from the RSD group. The amylase level was not changed in Expt 1 , but was increased in Expts 2 and 3 , the effect being consistent at both levels of methionine in the older age-group.

Since the results of the three experiments were not identical, it was difficult to conclude how the addition of methionine affected the levels of the digestive enzymes. From a more careful study of the problem it appeared that a relationship exists between the amylolytic enzyme activity and the proteolytic enzyme activity. In Expt I, in the fasted RSD chicks, a decrease in the proteolytic enzymes as a result of methionine supplementation was not accompanied by an increase in amylase activity. In Expt 2, however, the decrease in proteolytic activity was smaller than in Expt $\mathrm{I}$, but there was a more pronounced increase in amylase. In Expt 3 the addition of methionine caused an increase in amylolytic enzymes and a decrease in proteolytic enzymes. Therefore, it seems that methionine supplementation causes a change in the ratio of amylolytic to proteolytic enzyme levels in favour of the former. In order to check this hypothesis, the ratio of amylase to each protease in the pancreas of each chick was calculated and statistically analysed for its significance. The results of this analysis are presented in Table 2.

The addition of methionine to both HSD and RSD caused the ratio of amylolytic to proteolytic activity to shift consistently in favour of the amylolytic enzymes. This phenomenon was most marked in the fasted RSD group, less in the fed RSD and fasted HSD, and least in the fed HSD chicks. However, as a result of the large variability, the differences in those ratios between the unsupplemented versus the methionine-supplemented diets were not always statistically significant. No consistent difference was observed between the results for the $0.3 \%$ and those for the $0.6 \%$ methionine-supplemented diets.

These results confirm the earlier hypothesis (Gertler \& Nitsan, 1970) that the limited biosynthesis of amylase by RSD-fed chicks compared with HSD-fed chicks, supplemented by trypsin inhibitors, is a result of methionine deficiency. This conclusion is further substantiated by the finding of Konijn, Birk \& Guggenheim ( 1970 ) that the pancreas of rats given RSD not supplemented by methionine incorporated less $\left[{ }^{14} \mathrm{C}\right]$ valine into amylase and more into trypsinogen and chymotrypsinogen, than did the pancreas of rats given HSD. The increase in the ratio of amylolytic to proteolytic activities was most pronounced in the fasted RSD chicks, because during fasting there was an accumulation of enzymes in the pancreas as a result of decreased secretion. Therefore, the level of enzymes found in the pancreas of fasted chicks is a better indicator of the capacity for synthesizing digestive enzymes than the level in fed chicks. 


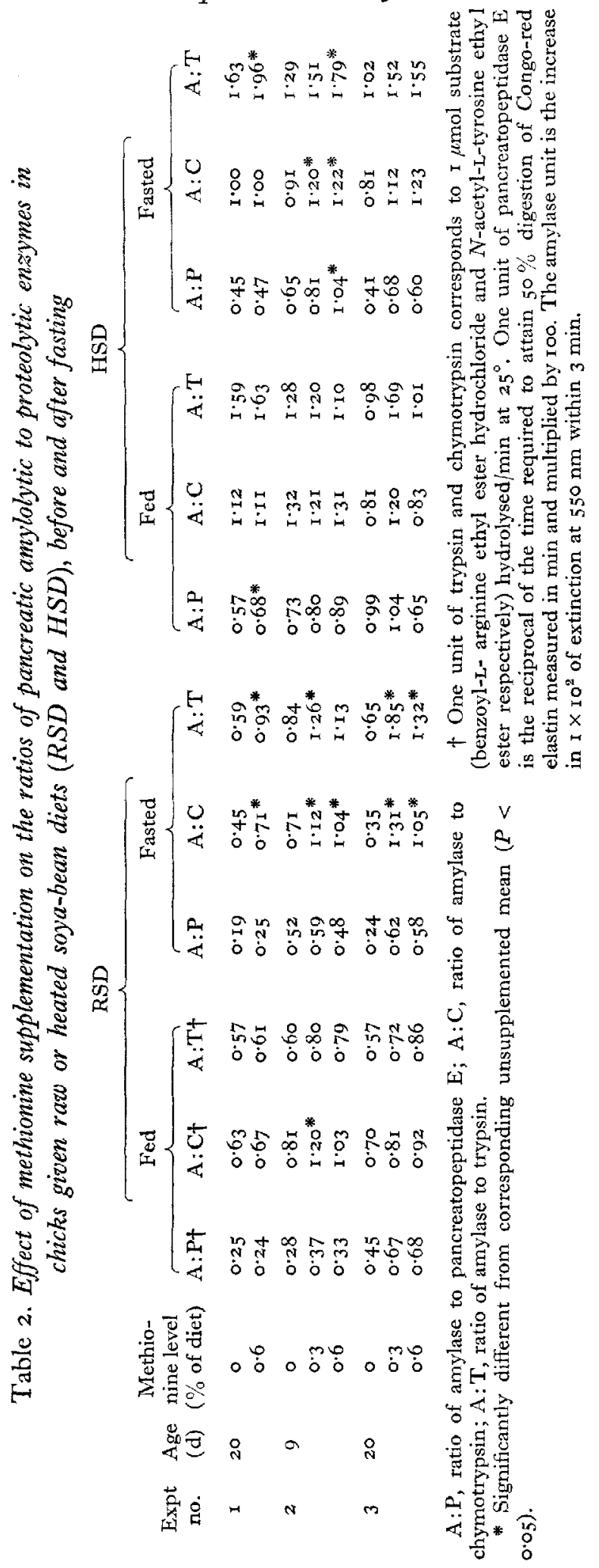


We thank Professor Yehudith Birk and Professor A. Bondi for their interest in the work and helpful suggestions, and gratefully acknowledge the technical assistance of Mrs Z. Zoref and Miss G. Tinman.

\section{REFERENCES}

Almquist, H. J., Mecchi, E., Kratzer, F. H. \& Grau, C. R. (1942). F. Nutr. 24, 385.

Barnes, R. H., Fiala, G. \& Kwong, E. (1962). F. Nutr. 77, 278.

Barnes, R. H. \& Kwong, E. (1965). \%. Nutr. 86, 245.

Gertler, A. \& Nitsan, Z. (1970). Br. F. Nutr. 24, 893 .

Konijn, A. M., Birk, Y. \& Guggenheim, K. (I970). Am. F. Physiol. 218, 1113.

Kwong, E. \& Barnes, R. H. (1963). Fedn Proc. Fedn Am. Socs exp. Biol. 22, 202.

Lepkovsky, S., Koike, T., Sugiura, M., Dimick, M. K. \& Furuta, F. (1 g66). Br. F. Nutr. 20, 42 I.

Neurath, H. (196r). In Exocrine Pancreas p. 76 [A. V. S. DeReuck and M. P. Camcron, editors]. Boston, Mass.: Little, Brown.

Snedecor, G. W. (1962). Statistical Methods 5 th ed. Ames, Iowa: The Iowa State College Press. 